\title{
Pentingnya Integrated Marketing Communication Bagi Penggiat Pariwisata Kabupaten Belitung Timur
}

\author{
Salman ${ }^{1)}$ Heppy New Year Haloho ${ }^{2)}$ Emmy Agustia ${ }^{3)}$ \\ Ilmu Komunikasi, Fakultas Ekonomi dan Bisnis Institut Teknologi dan Bisnis Kalbis \\ Jalan Pulomas Selatan Kavling 22, Jakarta 13210 \\ 1)Email: salman.naning@kalbis.ac.id \\ ${ }^{2)}$ Email: heppy.haloho@kalbis.ac.id
}

\begin{abstract}
This community service activity is given to tourism activists in East Belitung Regency. How to promote existing tourism by using integrated marketing communication activities. Many tourist locations in East Belitung regency are unknown to the public. The public knows more about Belitung. For this reason, branding is needed related to these tourist objects. The method used in this service The method in this PKM activity uses a distance training method by utilizing communication technology and information from the zoom meeting application
\end{abstract}

Keywords: beltim branding, East Belitung, integrated marketing communication, Tourism

\begin{abstract}
Abstrak: Kegiatan pengabdian kepada masyarakat ini, diberikan kepada penggiat pariwisata Kabupaten Belitung Timur. Cara mempromosikan wisata yang ada dengan menggunakan kegiatan komunikasi pemasaran terpadu. Banyak lokasi wisata di kabupaten Belitung Timur yang selama ini tidak diketahui oleh khalayak. Masyarakat lebih mengetahui Belitungnya saja. Untuk itu diperlukannya branding terkait objek wisata tersebut. Metode yang digunakan dalam pengabdian ini Metode dalam kegiatan PKM ini menggunakan metode pelatihan jarak jauh dengan memanfaatkan teknologi komunikasi dan infromasi aplikasi zoom meeting
\end{abstract}

Kata kunci: branding beltim, East Belitung, komunikasi pemasaran terpadu, pariwisata

\section{PENDAHULUAN}

Pariwisata merupakan salah satu pendapatan devisa terbesar, disamping produk komoditas lainya. Untuk menjadikan pariwisata sebagai tujuan wisata bagi para wisatawan baik dalam negeri maupun luar negeri, maka kegiatan pariwisata di suatu tempat harus diperkenalkan kepada khalayak. Tidak terkecuali kabupaten Belitung timur provinsi Bangka Belitung.

Untuk mendukung pengenalan tersebut, diperlukannya pengetahuan yang memadai bagi para penggiat pariwisata Belitung timur. Para penggiat diberi wawasan cara memasarkan dan memperkenalkan objek-objek wisata yang sangat banyak dan menarik untuk diketahui oleh masyarakat yang gandrung akan bepergian ke objek - objek wisata. Menjawab kebutuhan masyarakat yang kerap gandrung pada wisata, diperlukan tenaga profesional yang mampu menarik minat masyarakat tersebut. Tenaga professional tesebut harus dilatih dan diberikan pengetahuan jenis-jenis promosi yang dapat dilakukan sehingga objek wisata tersebut menjadi tujuan utama para wisatawan tersebut. Untuk itu, sebagai salah satu bentuk Tri Dharma Perguruan Tinggi, yaitu pengabdian kepada masyarakat, Program Studi Ilmu Komunikasi Kalbis Institute akan mengusulkan program pelatihan komunikasi pemasaran terpadu (Integrated Marketing Communication) kepada para penggiat wisata di kabupaten Belitung Timur, provinsi Bangka Belitung.

Pelatihan ini bertujuan untuk memberikan keterampilan praktis dalam Ilmu Komunikasi, khususnya mengenai kegiatan komunikasi pemasaran terpadu. Kegiatan pengabdian kepada masyarakat ini akan diselenggarakan pada Senin, 15 Juni 2020, di lakukan dengan menggunakan zoom meeting, sehingga kegiatan pengabdian ini dapat menjangkau seluruh peserta yang berada di pelosok / lokasi wisata di kabupaten Belitung Timur. Sedangkan sebagai pemberi materi berada di kampus Kalbis Institute. Jl. Pulomas Selatan Kav. 22 Jakarta Timur.Kegiatan kali ini merupakan tahap pertama dari rangkatain kegiatan pengabdian kepada masyarakat, yang diselenggarakan atas kerjasama Kalbis Institute Jakarta dengan Dinas Budaya dan Pariwisata kabupaten Belitung Timur, Provinsi Bangka Belitung.

\section{METODE PELAKSANAAN}

Metode dalam kegiatan Pengabdian kepada Masyarakat ini menggunakan metode pelatihan jarak jauh dengan memanfaatkan teknologi 
komunikasi dan infromasi aplikasi zoom meeting. Tim Pelaksana kegiatan Pengabdian Kepada Masyarakat menyiapkan sarana yang dibutuhkan seperti menyiapan perangkat teknoogi yang mendukung seperti laptop, telepon pintar (Smartphone). Sarana aplikasi zoom meeting bisa diikuti oleh seluruh peserta mitra kegiatan PKM. Dengan, pendekatan pendekatan kualitatif, dimana tim pelaksana PKM menyampaikan materi dan mengukur penyampaian tersebut berdasarkan pengalaman serta proses dialog, tanya jawab dan diskusi dengan pihak mitra.

\section{A. Pelatihan tersebut meliputi rangkaian materi sebagai berikut:}

Mengapa perlu IMC dalam memasarkan pariwisata; Apa manfaat kegiatan IMC; Elemenelemen kegaitan IMC; dan one voice dalam kegiatan promosi pariwisata;

\section{B. Waktu Efektif Pelaksanaan Kegiatan}

Pelaksanaana kegiatan PKM adalah sebagai berikut:

Judul: PelatihanIntegrated Marketing Communication

bagi penggiat pariwisata kabupaten Belitung

Timur.

Hari/Tanggal : Senin, 15 Juni 2020

Tempat : Zoom meeting

Susunan Acara Kegiatan Pelatihan Integrated Marketing Communication bagi penggiat pariwisata kabupaten Belitung Timur. Seperti pada Tabel 1.

Table 1 Susunan acara pelatihan.

\begin{tabular}{|l|l|}
\hline $08.00-09.00$ & Persiapan sarana zoom meeting \\
\hline $09.00-09.15$ & Pembukaan oleh Host \\
\hline $09.15-09.30$ & $\begin{array}{l}\text { Sambutan-sambutan dari Prodi } \\
\text { Ilmu Komunikasi dan dinas } \\
\text { pariwisata kabupaten Belitung } \\
\text { Timur }\end{array}$ \\
\hline
\end{tabular}

\section{HASIL DAN PEMBAHASAN}

Kabupaten Belitung Timur merupakan kabupaten yang berada di Provinsi Kepulauan Bangka Belitung. Kabupaten Belitung Timur merupakan pemekaran dari Kabupaten induk Belitung, yang beribu kota Manggar.

Kabupaten Belitung Timur merupakan lokasi pertambangan timah sejak masa pemerintahan kolonial Belanda hingga masa Orde Baru. Lambat laun kabupaten ini mulai menggiatkan objek wisatanya sebagai tujuan utama pariwisata bagi wisatawan local maupun wisatawan dalam negeri.
Banyak objek wisata alam yang dimiliki oleh Belitung timur, merupakan suatu keuntungan tersendiri. Disamping ojek wisata bahari, kuliner, budaya. Kemungkinan besar masih adanya objek wisata yang masih tersembunyi yang belum banyak diketahui lainnya. Dengan memiliki objek wisata bermacam tersebut, Belitung timur harusnya bias menjadi tujuan utama wisatawan untuk melepaskan lelah dari kebisingan kota dan tugas dan pekerjaan yang melelahkan. Namun, saat ini Belitung Timur belum menjadi tujuan utama wisatawan, dikarenakan masih belum dikenal luas oleh masyarakat.

Jenis Mitra dari kegiatan pengabdian kepada masyarakat yang diseleggarakan program studi Ilmu Komunikasi, merupakan kelompok penggiat pariwisata kabupaten Belitung Timur Propinsi Bangka Belitung. Jumlah Mitra merupakan para penggiat pariwisata kabupaten Belitung Timur yang berjumlah 48 orang. Kondisi mitra merupakan penggiat pariwisata kabupaten Belitung timur yang memiliki latar belakang beragam, ada yang berlatar lembaga swadaya masyarakat (LSM) yang peduli akan kelestarian dan kebudayaan Belitung Timur, Pelaku pariwisata kabupaten Belitung Timur dan juga ASN yang berdinas di kabupaten Belitung TImur.

Latar Belakang Pendidkan yang menjadi Mitra PKM adalah penggiat pariwisata kabupaten Belitung timur bervariasi mulai dari lulusan Sekolah Menengah Atas (SMA) sederajat sampai berpendidikan Strata dua (S2).

Berdasarkan uraian di atas, terangkum beberapa persoalan yang timbul terkait dalam bidang akademis. Diharapkan ke depan akan membantu dinas pariwisata untuk mempromosikan dan meningkatkan jumlah kunjungan wisata ke kabupaten Belitung timur, yaitu:

"Masalah peningkatan keterampilan dan pengetahuan di bidang ilmu komunikasi bagi siswapenggiat wisata kabupaten Belitung Timur, khususnya kegiatan Integrated Marketing Communication.”

Mitra dalam kegiatan Pengabdian Kepada Masyarakat pelatihan Integrated Marketing Communication diikuti oleh peserta Laki-laki dan Perempuan berusia antara 25 tahun -50 tahun.

Dinas Kebudayaan dan Pariwisata Kabupaten Belitung Timur Kabupaten Bangka Belitung. Seperti pada Gambar 1.

Mitra dapat dijangkau dengan telepon, dan perangkat teknoogi komunikasi lainnya seperti video call, zoom meeting. Dimana saat ini tidak terdapat kendala yang berarti dalam melakukan komunikasi dengan mitra walaupun mitra berada jauh dari prodi ilmu komunikasi. 


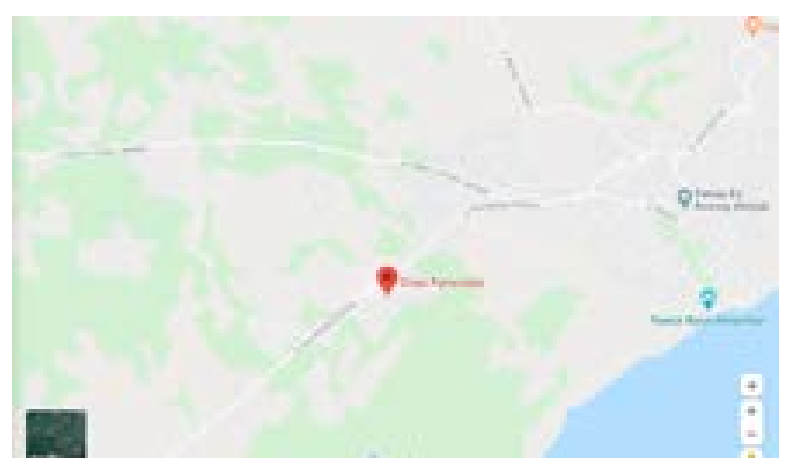

Gambar 1. Peta Lokasi Dinas

Pariwisata Belitung Timur

Konsep yang secara umum sering digunakan untuk menyampaikan pesan adalah apa yang disebut bauran promosi atau bauran pemasaran. Di dalam bauran pemasaran ini biasanya sering digunakan berbagai jenis promosi. Terdapat sebelas baruan dalam komunikasi pemasaran offline, yaitu: (1) Advertising; (2). Public Relations; (3) Sponsorship; (4). Sales Promotion; (5). Direct Mail; (6). Sales Force; (7). Packaging; (8). Point of Sale; (9). Retail store design or commercial offices; (10). Exhibition and conferences; dan (11). Word of mouth. (Smith; 2011, 24).

Dari sebelas bauran pemasaran tersebut, umumnya hanya lima besar jenis bauran promosi yang digunakan. Menurut Kotler lima unsur tersebut, yaitu : Periklanan (advertising), penjualan langsung (personal selling), promosi penjualan (sales promotion), Humas (Public Relations), dan pemasaran langsung (Direct marketing). (Kotler; 2000:626)

\section{Periklanan (Advertising)}

Periklanan adalah segala bentuk penyajian dan promosi bukan pribadi mengenai gagasan, barang dan jasa yang dibayar oleh sponsor tertentu.

Iklan sebaiknya dirancang untuk mencapai sasaran spesifik dari pemasar, walaupun tujuan akhir dari program periklanan adalah untuk mendorong terjadinya keputusan pembelian oleh konsumen. Estimasi dampak periklanan terhadap pembeli membantu manajemen menentukan peran dan lignkup iklan, dalam program pemasaran dan memilih tujuantujuan tertentu, klan mana yang dapat membantu pencapaian tujuan promosi mempunyai pengaruh penting dalam menentukan peran periklanan. Periklanan merupakan fungsi komunikasi pemasaran yang secara spesifik digunakan untuk menjangkau target audience tertentu selama suatu periode tertentu. Hal ini terkait dengan spesifikasi tujuan periklanan. Bagi produk baru maupun produk lama yang melakukan perubahan harga, periklanan dapat digunakan sebagai alat informasi, yang juga dapat digunakan untuk mempengaruhi konsumen untuk membeli, disamping periklanan sebagai reminding untuk menjaga brand produk agar tetap eksis dibenak konsumen dalam persaingan.

Strategi periklanan dapat dibagi menjadi dua, yaitu: 1). Strategi pesan (message strategy), dalam strategi ini harus memperhatikan keunggulan dan positioning produk dalam suatu blue print yang dikenal dengan creative concept. Konsep kreatif menghasilkan suatu pendekatan dalam suatu kampanye periklanan. Beberapa hal yang perlu diperhatikan dalam merumuskan pendekatan kreatif adalah keberartian bagi target audience, kemampuan untuk dipercaya, dan kemampuan untuk berbeda, sehingga dapat menciptakan memorability dibenak konsumen; dan 2). Strategi Media (Media strategy), berkaitan dengan pemilihan media yang tepat sebagai sarana periklanan kepada target audiencenya. Terdapat beberapa hal yang dapat dijadikan rujukan, yaitu: menentukan reach (persoalan luas exposure), frekuensi serta dampak kepada target audience. Menetapkan ide dan karakter media yagn digunakan seperti media cetak atau elektronik, Menyeleksi tipe dan karakter media secara spesifik. Menentukan waktu yang tepat, seperti saat musim penerimaan mahasiswa baru untuk iklan perguruan tinggi.

\section{Penjualan langsung (Personal Selling)}

Penjualan langsung adalah presentasi pribadi oleh tenaga penjual dari perusahaan dengan tujuan menjual dan membina hubungan dengan pelanggan.

Penjualan langsung merupakan satu-satunya alat promosi yang digunakan untuk berkomunikasi dengan konsumen potensial secara langsung. Artinya penjualan langsung merupakan aktivitas komunikasi antara produsen yang diwakili oleh tenaga penjual dengan konsumen potensial melibatkan pikiran dan emosi, serta tentu saja berhadapan langsung dengan konsumen potensial, penjualan tatap muka mempunyai kelebihan dibandingkan dengan alat promosi lainnya. Keunggulan dalam penjualan tatap muka adalah melibatkan komunikasi langsung dengan konsumen potensialpesan penjualan dapat langsung membujuk konsumen untuk membeli dari pada iklan.

\section{Promosi penjualan (Sales Promotion)}

Promosi adalah insentif jangka pendek untuk mendorong pembelian atau penjualan dari suatu produk atau jasa. Promosi penjualan merupakan upaya pemasar yang bersifat media dan non media 
untuk merangsang minat konsumen, meningkatkan permintaan dari konsumen atau untuk memperbaiki kualitas produk. Upaya dari promosi penjualan digunakan dalam jangka pendek. Salah satu hal yang penting adalah bagaimana mengelola berbagai fungsi promosi penjualan. Walaupun kegiatan-kegiatan ini digunakan untuk mendukung periklanan, penetapan harga, saluran distribusi, dan strategi penjualan perorangan, namun besar dan lingkup promosi penjualan menganjurkan bahwa tanggung jawab untuk mengelola program ini seharusnya dibebankan kepada salah seorang eksekutif. Paling tidak kepala eksekutif pemasaran harus mengkoordinasikan dan mengevaluasi kegiatan-kegiatan promosi penjualan.

Pada intinya promosi penjualan merupakan suatu teknik untuk menciptakan insentif jangka pendek untuk mendorong pembelian atau penjualan dari suatu produk barang atau jasa. Beberpa perangkat promosi penjualan yang dapat digunakan, antara lain seperti: sample produk yang diberikan secara CumaCuma kepada konsumen untuk dicoba (trial), kupon (voucer), potongan harga (rebate).

\section{Hubungan Masyarakat (Public Relations)}

Humas adalah membina hubungan baik dengan berbagai kelompok masyarakat yang berhubungan dengan perusahaan melalui publisitas yang mendukung, membangun "citra perusahaan" yang baik dan menangani atau meredam isu, cerita dan peristiwa yang dapat merugikan, yang dipandang sebagai aktivitas untuk mempromosikan perusahaan atau produknya dengan memuat berita mengenai subjek itu tanpa dibayar oleh sponsor.

Pada kenyataannya baik disadari atau tidak disadari setiap organisasi setiap organisasi mempunyai hubungan masyarakat baik diinginkan maupun tidak. Definisi hubungan masyarakat menunjukkan bahwa aktifitas hubungan masyarakat memerlukan keahlian komunikasi agar menghasilkan respon yang diinginkan. Respon yang diinginkan tentu saja dari berbagai macam masyarakat yang menjadi konstituennya. Dalam definisi ini terkandung makna bahwa komunikasilah cara yang paling baik untuk membangun respon positif dari masyarakat.

Pada umumnya, public relations menjalankan beberap tugas, seperti : press release yang membina hubungan baik dengan media, product publicity yang berhubungan dengan publisitas suatu produk, public affairs, membangun dan membina hubungan baik dengan penentu kebijakan seperti pemerintah bertujuan menguntungkan perusahaan, public relations juga membina hubungan baik dengan shareholder maupun komunitas finansialnya (investor relations), public relations juga menjalankan fungsi socoal responsibility dengan mengeluarkan berbagai donasi atau kerjasama dengan lembaga-lembaga lain (non profit organization) guna mendapatkan citra (community development).

\section{Pemasaran Langsung (Direct Marketing)}

Penggunaan surat, telepon, faksimili, e-mail, dan alat penghubung non personal lain untuk berkomunikasi secara langsung dengan atau mendapatkan tanggapan langsung dari pelanggan dan calon pelanggan tertentu.

Pemasaran langsung adalah sub disiplin dari pemasaran yang memfokuskan untuk mempengaruhi konsumen pada pembelian. Sistem pemasaran ini menggunakan suatu media iklan atau lebih guna mendapat respon pada lokasi tertentu. Upaya rekayasa pemasarana suatu produk tidak bisa lagi hanya mengandalkan iklan seperti yang biasa dilakukan oleh pengusaha belakangan ini. Dengan menggunakan tenaga penjualan, lama-lama memerlukan biaya tinggi. Pemasaran langsung juga dapat memberikan keuntungan atau manfaat pada konsumen.

\section{SIMPULAN}

Pelaksanaan kegiatan PKM prodi Ilmu komunikasi Kalbis Institute dengan mitra dinas pariwisata dan kabupaten Belitung Timur, dapat terselenggara dengan baik, lancer dan memberikan manfaat bagi para peserta yang mengikuti pelatihan Integrated Marketing Communication.

Kegiatan yang memanfaatan teknologi informasi dan komunikasi berbasis internet dengan aplikasi zoom meeting memiliki keistimewaan tersendiri. Dikarenakan hal ini merupakan sesuau yang baru dalam penyelenggaraan pengabdian kepada masyarakat. Masih banyaknya peserta yang masih belum terbiasa dengan "new normal" pelatihan daring secara langsung. Terkadang suara suara yang terdengar saat pemateri menyampaikan materi.

Tetapi, pada prinsipnya penyelenggaraan pelatihan ini berjalan lancara sesuai dengan target. Hal ini dapat dilihatsebagai berikut: 1) Para peserta antusias untuk mendapatkan materi yang disajikan dari perguruan tinggi yang berada di Jakarta, sementara peserta berada di desa dan kecamatan d Belitung timur; 2) Peserta aktif berdiskusi tentang pemanfaatan Integrated Marketing Communication; dan 3) Peserta 
kegiatan PKM ini, memahami pentingnya promosi untuk menarik para wisatawan sehingga dengan banyaknya wisatawan yang berkunjung, akan meningkatan perekonomian masyarakat yang berada di wilayah Kabupaten Belitung Timur.

\section{DAFTAR RUJUKAN}

Damanik, J. (2013). Pariwisata Indonesia Antara Peluang dan Tantangan. Yogyakarta: Pustaka Pelajar
Handinoto, K. (1996). Perencanaan Pengembangan Destinasi Pariwisata. Jakarta: Universitas Indonesia..

Hasan, A. (2015). Tourism Marketing. Yogyakarta: CAPS.

Kotler, P. (2000). Prinsip - Prinsip Pemasaran Manajemen, Jakarta : Prenhalindo

Pitana, I G. \& Diarta, I. K. S. (2009). Pengantar Ilmu Pariwisata. Yogyakarta: ANDI.

Terence, S. (2003). Periklanan Promosi. Jakarta: Erlangga. 